\title{
Evaluation of Performance by Operating Process Improvement Modeling on a Company with Pump Manufacturing
}

\author{
Pompa İmalatı Yapan Bir Firmada Süreç İyileştirme Modellemesiyle İşletmenin Performansının \\ Değerlendirilmesi
}

\author{
Ahmet Talat İNAN ${ }^{1}$ (D), Mehmet Akif KARTAL ${ }^{2}$ iD \\ ${ }^{1}$ Marmara University, Faculty of Technology, Department of Mechanical Engineering, 34722, Göztepe - İstanbul / Turkey \\ ${ }^{2}$ Bandırma Onyedi Eylül University, Central Campus, 10200, Bandırma - Ballkesir / Turkey
}

\begin{abstract}
There may be more than one element affecting quality and efficiency in the manufacturing organizations. As a result of multiple elements occurring at the same time, permanent losses occur in final production and quality. Both the customer sense of trust and their satisfaction are negatively affected because of those problems.

Failure to achieve targeted levels of quality and productivity in the organization reduces customer satisfaction. Quality and productivity in the organization are affected by inefficiency in resource utilization, bottlenecks in the production and inefficient workflow design within the organization.

This study aims to improve production process in a manufacturer of air operated diaphragm pumps by simulation analysis. Most efficient way of utilizing raw materials, manpower, vehicles and equipment is sought by simulation based process improvement. Discrete-event simulation software (Arena) is used to detect problems in the production process such as: transportation, blockage and/or layout. Simulation is used to experiment with process improvement approaches without making changes in the real-world production system.

Simulation models of the current state and the proposed future state with improvements to the layout of the production system are created. The results from the models were compared with each other and evaluations were made. The future state simulation model utilizes existing resources for process improvement, without the requirement for additional resource acquisition. Comparison of current state model and future state model simulation output data, suggests a $67 \%$ increase in the number of products produced per month. It is foreseen that this increase can greatly affect the operational efficiency and future managerial decisions, and suggestions are made for future works.
\end{abstract}

Keywords: Assembly Line, Process Improvement Simulation, Pump, Pump Process Improvement.

Öz

İmalat organizasyonlarında kaliteyi ve verimliliği etkileyen birden fazla unsur olabilir. Aynı anda meydana gelen çoklu elemanların bir sonucu olarak, nihai üretim ve kalitede kalıcı kayıplar meydana gelir. Bu sorunlar nedeniyle hem müşteri güven duygusu hem de memnuniyeti olumsuz yönde etkilenmektedir.

Kuruluşta hedeflenen kalite ve verimlilik seviyelerinin sağlanamaması müşteri memnuniyetini azaltır. Kurumdaki kalite ve verimlilik, kaynak kullanımındaki yetersizlik, üretimdeki darboğazlar ve organizasyon içindeki yetersiz iş akışı tasarımından etkilenir.

Bu çalışma, simülasyonlu analizle hava ile çalışan bir diyafram pompa üreticisindeki üretim sürecini iyileştirmeyi amaçlamaktadır. Simülasyona dayalı süreç iyileştirme ile hammadde, insan gücü, araç ve gereç kullanmanın en etkili yolu aranmaktadır. Kesikli olay simülasyon yazılımı (Arena), üretim sürecindeki sorunları tespit etmek için kullanılır: ulaşım, tıkanma ve / veya düzen. Simülasyon, gerçek dünya üretim sisteminde değişiklik yapmadan süreç iyileştirme yaklaşımlarını denemek için kullanılır. 
Üretim sisteminin düzeninde iyileştirmelerle mevcut durumun ve önerilen gelecek durumun simülasyon modelleri oluşturulmuştur. Modellerin sonuçları birbirleriyle karşılaştırıldı ve değerlendirmeler yapıldı. Gelecekteki durum simülasyon modeli, ek kaynak edinme şartı olmadan, süreç iyileştirme için mevcut kaynakları kullanır. Mevcut durum modeli ve gelecekteki durum modeli simülasyonu çıktı verilerinin karşılaştırılması, ayda üretilen ürün sayısında \% 67 artış olduğunu göstermektedir. Bu artışın operasyonel verimliliği ve gelecekteki yönetim kararlarını büyük ölçüde etkileyebileceği ve gelecekteki çalışmalar için önerilerde bulunacağı öngörülmektedir.

Anahtar Kelimeler: Montaj Hattı, Süreç İyileştirme Simülasyonu, Pompa, Pompa Süreç İyileştirme.

\section{INTRODUCTION}

Production planning and control is a predetermined process, which includes the use of human resource, raw materials, machines etc. PPC is the technique to plan every step in a long series of separate operation. Therefore, it is the other name of the function that determines the levels or limits of the future activities and which takes precautions at the required times. Production planning and control functions and objectives are to organize the production facilities like machines, men, etc., to achieve stated production objectives with respect to quantity and quality time and cost. In addition, it is to conform to delivery commitments. Also, coordinate with other departments relating to production to achieve regular balanced and uninterrupted production flow.

Companies strive for continuous improvement of their business processes and production systems in order to main their competitiveness and/or status quo under fierce global competition. Therefore, it can be said that the importance of process management and process improvement is of great importance.

In recent year's textile and apparel companies in Turkey are threatened by increased competition especially from their Asian rivals that have the advantage of low labor costs. Therefore, companies should prioritize rational use of their resources and place emphasis on efficiency and efficacy of their business operations.

In most of the enterprises operating in the sector, there are basic problems such as inability to use resources effectively, bottlenecks in production lines or unbalanced workflows. These problems reduce efficiency / productivity; which adversely affects product quality, customer satisfaction and service levels.

In this study a simulation analysis based process improvement methodology is proposed to improve layout in a discrete parts manufacturer of diaphragm pumps which in turn positively affects productivity and quality levels. Simulation analysis point to problems in the current layout of the enterprise which hinder effective usage of resources. Current production process also includes bottlenecks and capacity utilization is lower than expected. The main purpose of this study is to propose a simulation analysis based methodology for layout improvement. Manufacturing system layout of a discrete parts manufacturer of diaphragm parts is analyzed to propose an improved future state with gains in productivity and quality levels.

In the second part of the study, information was given about the studies carried out on process improvement. In the third chapter, the application related to the process improvement in a pump manufacturer is explained. As a result, a general performance evaluation was made and recommendations were made for future studies.

\section{LITERATURE REVIEW ON PROCESS MODELING AND IMPROVEMENT}

This section includes a review of existing literature on process improvement in manufacturing sector.In the production management process, it is simply a series of operations where inputs are transformed into output through a production process. Process planning is the design and implementation of a production system that will enable the production of the desired product or service in the desired amount, at the most appropriate time and with acceptable cost [1]. Process management aims to ensure continuous monitoring and improvement of processes. Within this scope, continuous evaluation, analysis and improvements are carried out in order to design and maintain the processes and to better meet customer expectations and needs [2].

In a study carried out in the textile sector, bottlenecks in the production line of a manufacturer of jeans were identified and a process improvement was proposed to eliminate bottlenecks. A simulation based assembly line balancing approach was proposed and resulting improvements were analyzed. Comparison of future and current state simulation models indicate $47 \%$ improvement in productivity [3].

In the study carried out in an automotive supplier industry, physical resources such as labor, materials, machinery and equipment have been re-designed in a way to minimize the total material and transportation cost and process development has been studied. Effects machine-equipment layout changes on the manufacturing system performance were examined. In the study, LayOPT package program was used for the placement of the physical resources, and the new settlement plan and the improvements made by the ARENA simulation program were used to measure the performance 
of the new placement method and it was observed that the improvements have a positive affection the performance [4].

In a study carried out in an aviation company that collaborates with global partners such as Airbus and Boeing on research and development (RD) and manufacturing projects, a new manufacturing model was proposed that enhances quality control and improvement in the manufacturing process. The firm's current quality control approach is to avoid errors with close to $100 \%$ inspection. The proposed system has mechanisms that take into account changes in the variety and quantity of products, improvements in the system and capacity constraints. According to the results obtained from carrying out statistical process control, failure modes and effects analysis (FMEA) and measurement system analysis, quality levels were improved not just in the final product but also on other areas such as workforce training, lean production system and product design. [5].

Another study was conducted on Total Productive Maintenance (TPM); a general approach to maintenance that aims to improve production and quality levels. TPM is a guideline that aims to achieve zero percent failure and error goal with active participation from all level of employees. Results of the analysis indicate significant improvements in production levels as a result of changes in traditional maintenance approaches, continuous training, inter-departmental coordination, sharing of responsibility and usage of computer software [6].

Referring to the importance of methodical approach in machining optimization, Six Sigma study was conducted in the sector to reduce the breakage rate of cutting tools. Accordingly, cutting tool breaks have been reduced by $85 \%$, it earned a profit of over $€ 1000000$ [7].

The program of TRIZ, which has been used in design and manufacturing processes, has been carried out by using this technique which helps to develop creative solutions to problems in "Theory of Inventive Problem Solving". The implementation of TRIZ in the manufacturing process was discussed and the effects on the process were evaluated with the results of the sample application. The results show that TRIZ may contribute to the optimization of the manufacturing process [8].

In order to measure the effectiveness of business assets, a study was performed by using Overall Equipment Effectiveness (OEE) analysis. In this context, OEE analysis was carried out by expressing the equations related to machine and equipment conformity, performance efficiency, quality product ratio calculations in a firm that produces aspirators. A method for improvement such as single minute exchange of dies (SMED) and process planning was proposed. Results indicate improvement in process performance [9].

A process improvement study was carried out at the factory that manufactures hydraulic gear pumps. Engineering system analysis was made to improve material handling and man-machine utilization time. Man-machine utilization charts and Group Technology (GT) techniques were proposed to improve man-machine utilization and material handling [10].

Process development work was carried out in a company producing pump impellers. Since the propeller shape has a direct effect on the efficiency and performance of the pump, 3D designs have been made. According to propeller shape, performance and yield values were compared. According to the findings, the results of the propellers designed with the 3D designs made in place have been added to the yield and performance values [11].

A process improvement study was carried out for the transition to a lean manufacturing system in a company that uses batch production. Batch production; a production system in which similar or same-type products are produced in batches to meet a certain order or continuous demand. Lean manufacturing is a concept aimed at reducing waste, increasing quality and adding value to the company. Toyota Manufacturing System (TMS) is the precursor to lean manufacturing (LM) system with the latter born out of efforts of Western practitioners to adopt TMS to Western companies. The study synchronizes and increases adaptability of the manufacturing system using process improvement methods during transition to improve efficiency and performance. Transition from batch production system to lean manufacturing system resulted in improvements in levels of productivity, efficiency and performance rates [12].

Chan and Spedding examined quality and cost assessment with total Quality Management for business process restructuring and process improvement [13]. Schiefer emphasized the importance of case studies on the application of environmental management concepts in industry by attracting attention to environmental issues for process improvement and process efficiency in supply chain management [14].

Freire and Alarcon proposed an improvement methodology for the design processes of construction projects. In this study, it is aimed to ensure efficiency with improvements related to cycle times and waiting times [15]. Rohleder and Silver conducted a literature review on process improvement, emphasizing the strategic importance of business process improvement and, based on personal experience [16].

Kayışkan carried out process management practices and process improvement studies in a food business. The aim 
of this study is to determine the processes, measure the data related to the process, implement the process management, monitor the applications and improve the processes in the process through process improvement techniques [17].

The details of the process development project at BSH were studied [18]. Karaman has implemented corporate process improvement in a finance company [19]. Etleç (2017), by the application of the process improvements in lean manufacturing techniques have been applied in a cosmetics company [20].

A company that performs ice cream production was carried out. The current situation analysis was conducted by examining all stages of business processes. After the analysis, the problems were determined and the studies were carried out to solve the problems by selecting the appropriate methods. As a result of the application, the main problems were identified and workmanship errors, cleaning and hygiene, and factory layout solutions were produced. Some of the solutions produced have been implemented and provided significant improvements in a short time, while some of the proposals were evaluated by taking into consideration the medium-term targets of the organization [21].

The study focuses on Jishuken technique. In order to better understand the technique, the Japanese business management style, the logic of lean manufacturing and the philosophy of continuous improvement are explained. Then, the concepts and features of the Jishuken technique, training and implementation steps of the process, as well as the application of the method to show the selected examples were emphasized. The result of this study is that it is a recommended way of working to reduce unwanted costs in enterprises, to train qualified managers, to strengthen internal communication, to adopt the principle of continuous improvement of the managers, to adopt the process, to reduce the resistance to lean transformation in enterprises and to establish a working philosophy in the enterprise [22].

Şenol (2017), the energy saving potential of the pumps and pumping systems used in the water plant unit of an enterprise operating in the iron and steel sector was investigated. As a result, the energy consumption has been reduced from $240 \mathrm{kWh}$ to $109 \mathrm{kWh}$ in winter, and from $347 \mathrm{kWh}$ to 125 $\mathrm{kWh}$ in summer, bringing the total value from approximately $2.241 .000 \mathrm{kWh} /$ year to $920.000 \mathrm{kWh} /$ year [23].

Alpaslan (2018), conducted a process improvement study focused on customer satisfaction at an automotive service department [24].

\section{MATERIAL AND METHODS}

Computer simulation models are created to mimic the behavior of the real-world system. Simulation modeling provides us with the flexibility to work on the model of the engineering system considered, avoiding the difficulties associated with making changes in the real-world environment. Simulation modeling allows us to anticipate the effects of changes made to the engineering system before changes are made. In this study, Arena 13.0 discrete-event simulation software was used.

When developing a simulation model, a number of steps must be followed. These are; analysis of the system, formulation of the model, verification and validation of the model logic, planning of experiments, analysis and interpretation of results [25].

Simulation method has advantages and disadvantages as other methods. The advantages of the simulation method can be listed as follows:

- Most complex systems cannot be analytically evaluated and accurately defined by mathematical models. In such cases, simulation is the only research method.

- Simulation makes it easy to estimate an existing system according to changing conditions.

- It is possible to find out which of the proposed different system designs will best meet the desired target by simulation method.

- Once the model of the system is created, it can be used as many times as needed in the analysis of different situations.

- It is inexpensive to obtain data for the system.

- Simulation is the most appropriate method when system data is not very detailed.

- Simulation enables the examination of dynamic structures by emphasizing the universality of the systems.

The disadvantages of the simulation method can be listed as follows:

- Hide critical assumptions that invalidate the model,

- Not applicable to deterministic problems,

- May not propose a solution methodology,

- May not provide optimal solution,

- $\quad$ Requires expertise to build complex and comprehensive models,

- Data collection, modeling and analysis can be costly.

There are different package programs developed for simulation. In this study, ARENA 13.9 package program was used. 
Arena is a popular simulation program with a Windows interface developed by Systems Modeling Corporation, which also introduced Siman. Arena program includes detailed and comprehensive functions such as animation, analysis of input and output data required for successful simulation.

When creating a program model, Arena uses Siman commands to run the created model. But the feature of this program is that almost no command information is needed. In Arena, you can create your model program by adding the modules that are given shortcuts in the templates to your program page and by entering the desired information (arrival time, stack size, next station name, etc.) in the window that opens when you double-click these modules.

Since the Arena runs under Windows, it provides great convenience for working with toolbars, menus, and windows. The strength of the Arena model system is that it allows special applications in environments such as production, health sector, flow lines, computer networks. Therefore, it was deemed appropriate to use Arena simulation program.

Simulation was used as a method in the study. Simulation is the imitation of the behavior of the real system in a computer environment. Simulation provides important insights into what kind of changes we can make to a system without changing or stopping it. It also allows us to anticipate the impact of future changes to the system on the system.

The flowchart showing the steps of the simulation process can be expressed as follows:

- Problem identification,

- $\quad$ Setting up the computer model,

- $\quad$ Ensuring the validity of the model,

- Designing experiments

- Collecting necessary data,

- Performing the simulation,

- Evaluate statistical outputs,

- Review the simulation,

- Further data collection and analysis,

- $\quad$ Reporting

\subsection{Current Situation Simulation Model}

The following pictures are taken from the Arena program we used.

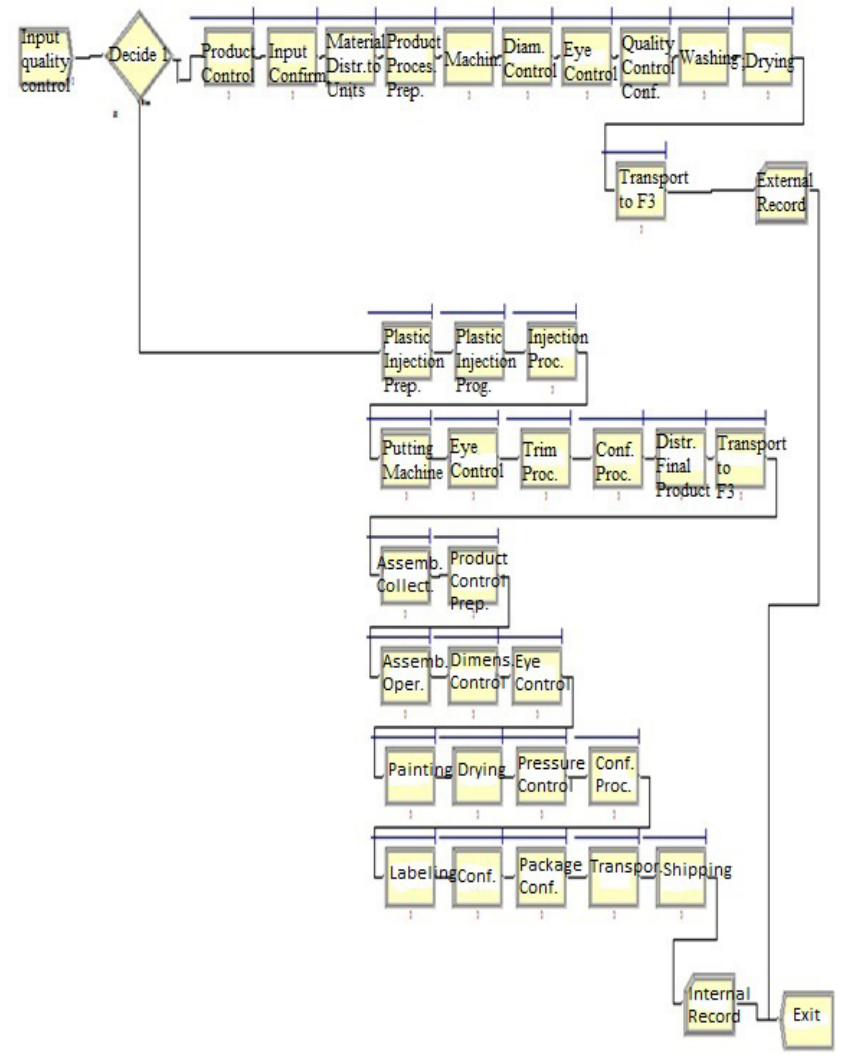

Figure 1. Current Situation Simulation Model

\subsection{Future Situation Simulation Model}

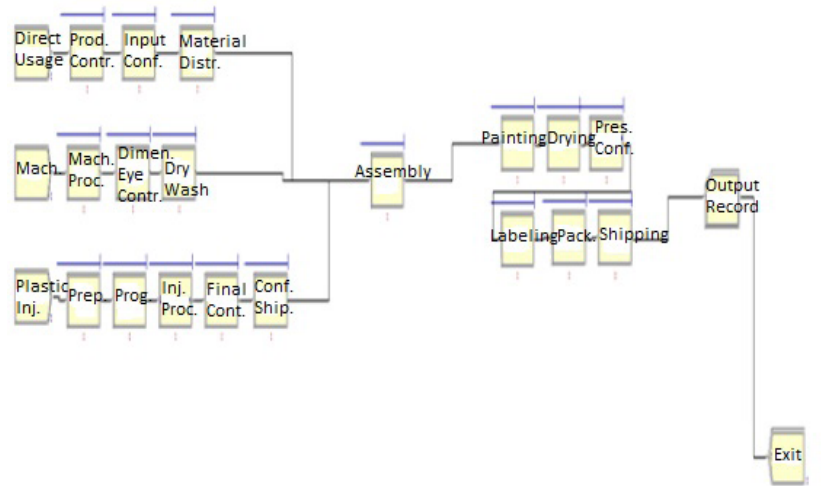

Figure 2. Future Situation Simulation Model

Verification: It is performed to verify that the simulation model reflects the real system in the same way. All the flows from the first entry to the system with the create module with the dispose module from the system are followed step by step and the inputs are passed through all the necessary steps in the system respectively. From this it was concluded 
that the system was verified. So the model represents the actual system adequately.

Validation: It is a stage in which the outputs obtained from the simulation model are compared with the outputs of the real system. At this stage, the outputs from the simulation and the outputs of the actual system are compared. If there is no statistically significant difference between the two main findings, it is concluded that the model is valid.

Finally, In the validity test phase of the model "Final Number of Products" is taken as performance measure. When the historical data of the real system for the 12-month period between January and December 2017 were obtained, it was seen that the number of final products was 4391. On the other hand, the number of final products obtained from the simulation model was found to be 4396 . The results were found to be very close to each other. It is concluded that the model has been verified.

Herein, future situation simulation model and current situation simulation model were created. In these models, each square box shows a process in production. The operation times of these processes is entered into the program according to the information received from the company. The compiled version of these data are given in Table 1. When this information is entered into the related operations and the model is executed, the result gives us the number of final products. In the same way, the future situation simulation model is developed and improvements are made and the final product number is obtained. The yield ratio is obtained by comparing these two final product numbers.

\section{APPLICATION}

\subsection{Firm's Basics}

Since 2001, the company has been producing diaphragm pumps, it is a medium-sized firm and has about 70 employees. It is a firm that manufactures both air and electric diaphragm pumps and has a wide place in domestic market and exports to many countries.

Pump manufacturing process involves sand casting of a component that is done at a subcontractor which is then shipped to the company. Sand-casted pump part is then machined, machining process is followed by production of the pump's diaphragm component using plastic injection. Pump assembly and quality control of the finished product takes place next. After quality inspection the pump is transferred to paint shop. The painted pump is then stored in the finished goods area.

\subsection{Product Flow in Firm}

The production flow diagram of the diaphragm pump is as follows [26]:

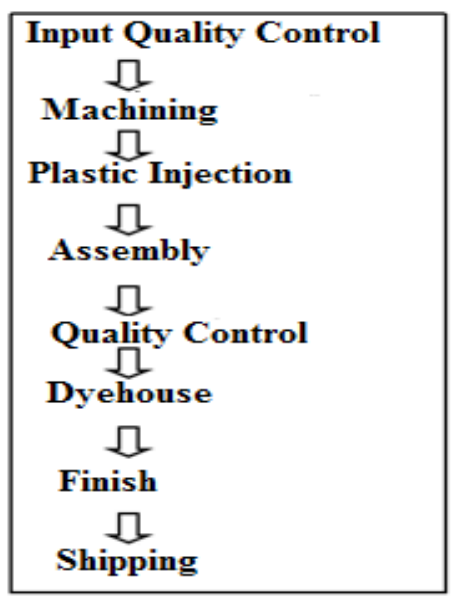

Figure 3. Production Flow Chart

In the ground floor of the manufacturing facility there is a quality control section for raw materials and semi-finished goods. The machining department is also located on the ground floor with multiple vertical milling machines and lathes with a storage area for machined components. Quality control section in the ground floor inspects incoming materials and if the procured material passes inspection approval is granted to use the material in downstream production processes. On the 2nd floor, a plastic injection machine produces several pump components in batches. A single batch of injection moulded parts are produced in a single production run followed by visual inspection and splitting of individual parts that are interconnected [27].

Painting shop and assembly area are located on the third floor where components are painted and assembled to create the finished product. Assembly area is separated from other areas by glass walls requiring movement of components to be assembled into this area manually. There is a final quality inspection of finished goods before shipping. If finished-product passes quality inspection, it is transported to the packaging area.

\subsection{Problems in Production Flow and the Proposed Future-State for Solving Those Issues}

The situation in which the process has been improved after the changes that are planned to be made in the current situation is shown by the future-state model. A number of improvements have been obtained with the future-state model. A 
number of problems have been observed in the current production flow. The main problems identified are [28]:

- It was determined that human resources and equipment was not utilized effectively in the shop-floor.

- Inefficient usage of workforce leads to lack of efficiency in production and decreases productivity.

- Line balancing becomes an issue since bottlenecks in the production process cannot be detected and remedied. For instance, insufficient number of personals was identified as a bottleneck in the production and the problem was solved by transferring personal from other departments to the assembly department.

- Even though the ground floor has adequate space, it is not used effectively since only the machining department is located at this floor. There are also problems with workflow since assembly, painting and quality control departments are located at the third floor. At the same time, the installation, paint shop and quality control departments on the third floor cause confusion in the workflow.

- Work flow and inter-departmental disturbances cause loss of time, which prevents timely delivery of products and therefore delivery times are usually not met [29].

- Overtime work is done to meet delivery times which leads to additional production costs and negatively affects employee performance. The rapid work done to meet the delivery times cause quality problems in the line and this prevents the coordination between the employees. Delays and quality problems arising from rapid work also negatively affect customer satisfaction and lead to loss of confidence [30].

- In the present case, a future simulation model is proposed to solve the above problems. To solve the space and workflow issues on the ground floor, it was suggested to carry the finishing and packaging section to the ground floor and to the assembly and paint shop area. Quality Control area on the third floor was moved to the second floor. Thus, it is estimated that lead-time and disturbances in production flow will be alleviated with new layout.

A number of arrangements have been made for the simulation model of the future and current state. These regulations are as follows:

- Several personnel were relocated to detected bottleneck operations in the assembly area from the quality control area since they were not used effectively in their current area.

- The quality control section was moved to the second floor. Thus, the time of transport of the materials is reduced.
- The joker milling machine in the machining section with low efficiency is placed as main band. Thus, performance and efficiency of the machining area was improved.

- The processed products section on the ground floor was removed from there and moved to an upper floor.

- Assembly and painting areas were relocated to the ground floor.

- Two personnel are relocated to the assembly section which is determined as a bottleneck and product collection and control operations have been made faster.

- $\quad$ The drying process of the parts from the machining process is taken from the ground floor

- In order to ensure interdepartmental coordination, the division of labor has been increased and the division of work that is done on the same workstation among workers has been eliminated. For instance, removal of part from the plastic injection machine and checking for defects was aggregated into a single operation to be completed using a single operator.

\subsection{Utilizing the Simulation Method to See the Impact of the Proposed Flow in the Future}

The proposed improved process for the future situation has been utilized as a result of the simulation method to see what will change in the current system and how the existing system will be affected. In this context, firstly, the current state simulation model was established and it was confirmed that this model represents the current system in full. Later on, a current state simulation model has been created by making some changes on the existing simulation model. It is seen that the proposed process for the future situation is effective by comparing the future situation simulation model with the outputs of the current situation simulation model.

\subsubsection{Current state simulation model for product flow in firm}

The scope of application is modeled by simulating the existing production flow simulation in the machining, plastic injection process, assembly, quality control, painting and finish sections. The ARENA 13.9 package program was used to create simulation models. Table 1 is shown that statistical distributions for operation times. 
Table 1. Statistical Distributions of Operation Times

\begin{tabular}{|c|c|c|c|}
\hline DEPARTMENT & OPERATION & DISTRIBUTION & \begin{tabular}{|l} 
TIME (MI- \\
NUTE)
\end{tabular} \\
\hline \multirow{4}{*}{$\begin{array}{l}\text { Input Quality } \\
\text { Control }\end{array}$} & Product Inspection & Expression & 75 \\
\hline & Input Confirmation & Expression & 30 \\
\hline & $\begin{array}{l}\text { Distribution of Mate- } \\
\text { rials to Units }\end{array}$ & Expression & 23 \\
\hline & $\begin{array}{l}\begin{array}{l}\text { Product Process Pre- } \\
\text { paration }\end{array} \\
\end{array}$ & Expression & 5 \\
\hline \multirow{7}{*}{ Machining } & Machining & Expression & 7 \\
\hline & Measure Control & Expression & 8 \\
\hline & Eye control & Expression & 2 \\
\hline & $\begin{array}{l}\text { Quality Control Ap- } \\
\text { proval }\end{array}$ & Expression & 10 \\
\hline & Washing & Expression & 12 \\
\hline & Drying & Expression & 45 \\
\hline & Moving to $3^{\text {rd }}$ Ground & Expression & 35 \\
\hline \multirow{9}{*}{$\begin{array}{l}\text { Plastic Injec- } \\
\text { tion Depart- } \\
\text { ment }\end{array}$} & $\begin{array}{l}\text { Plastic Injection Pre- } \\
\text { paration }\end{array}$ & Expression & 12 \\
\hline & $\begin{array}{l}\text { Plastic Injection Prog- } \\
\text { ramming }\end{array}$ & Expression & 8 \\
\hline & Injection Process & Expression & 6 \\
\hline & $\begin{array}{l}\text { Taking of the product } \\
\text { from the machine }\end{array}$ & Expression & 2 \\
\hline & Eye Control Process & Expression & 2 \\
\hline & Trimming Process & Expression & 2 \\
\hline & Approval Process & Expression & 3 \\
\hline & $\begin{array}{l}\text { Separation to the fi- } \\
\text { nished product se- } \\
\text { ction }\end{array}$ & Expression & 3 \\
\hline & $\begin{array}{l}\text { Dispatch Process to } \\
3^{\text {rd }} \text { Ground } \\
\end{array}$ & Expression & 35 \\
\hline \multirow{5}{*}{ Assembly } & Collecting Parts & Expression & 45 \\
\hline & Product Preparation & Expression & 12 \\
\hline & Mounting Operation & Expression & 32 \\
\hline & Dimension Control & Expression & 5 \\
\hline & $\begin{array}{l}\text { Eye Control Ope- } \\
\text { ration }\end{array}$ & Expression & 2 \\
\hline \multirow{4}{*}{ Dyehouse } & Dyeing Process & Expression & 10 \\
\hline & Drying Process & Expression & 120 \\
\hline & $\begin{array}{l}\text { Pressure Control Ope- } \\
\text { ration }\end{array}$ & Expression & 20 \\
\hline & Approval Operation & Expression & 5 \\
\hline \multirow{5}{*}{ Finish } & Labeling Operation & Expression & 2 \\
\hline & Approval Products & Expression & 15 \\
\hline & Packaging Operation & Expression & 10 \\
\hline & Trucking & Expression & 75 \\
\hline & Shipment Operation & Expression & 55 \\
\hline
\end{tabular}

\subsubsection{Verification of the current state of the simulation model and validity testing}

Verification: It is performed to verify that the simulation model reflects the real system in the same way. All the flows from the first entry to the system with the create module with the dispose module from the system are followed step by step and the inputs are passed through all the necessary steps in the system respectively. From this it was concluded that the system was verified. So the model represents the actual system adequately.

Validation: It is a stage in which the outputs obtained from the simulation model are compared with the outputs of the real system. At this stage, the outputs from the simulation and the outputs of the actual system are compared. If there is no statistically significant difference between the two main findings, it is concluded that the model is valid.

In the validity test phase of the model "Final Number of Products" is taken as performance measure. When the historical data of the real system for the 12-month period between January and December 2017 were obtained, it was seen that the number of final products was 4391. On the other hand, the number of final products obtained from the simulation model was found to be 4396 . The results were found to be very close to each other. It is concluded that the model has been verified.

\subsection{Analysis of Simulation Results and General Evaluation of Simulation Results}

In the future status simulation model, more resources of the same quality are provided by working with the same resources without adding extra resources with the existing resources. The final product number, which is taken as the performance criterion, is compared according to the current situation simulation model and the data obtained from the future situation simulation model. According to the current situation simulation model data, the one-year number of Final Products was 4396 and the number of Final Products was 366 per month.

On the other hand, according to the data of the future case simulation model, the one-year number of Final Products was 7352 and the number of Final Products was 613 per month. It is determined that there are 2956 differences between the current situation simulation model and the final product number of the future situation simulation model and 246 items per month. Based on these findings, it is seen that there is a $67 \%$ increase in the number of the final case simulation model compared to the current situation simulation model data. 
Table 2. Comparisons of Data Obtained from Present Status Simulation Model and Data Obtained from Future Status Simulation Model

\begin{tabular}{|c|c|c|}
\hline Period & $\begin{array}{c}\text { Data from the Current Situation } \\
\text { Simulation Model } \\
\text { (Final Number of Products) }\end{array}$ & $\begin{array}{c}\text { Data from the Fu- } \\
\text { ture Situation Simu- } \\
\text { lation Model } \\
\text { (Final Number of } \\
\text { Products) }\end{array}$ \\
\hline 12 Months & 4396 & 7352 \\
\hline Average & 366 & 613 \\
\hline Increase & & $\mathbf{\% 6 7}$ \\
\hline
\end{tabular}

Table 3. Comparisons of Time Data Obtained from Present Status Simulation Model and Data Obtained from Future Status Simulation Model

\begin{tabular}{|c|c|c|c|}
\hline VA Time (Minute) & Average & $\begin{array}{c}\text { Minimum } \\
\text { Value }\end{array}$ & Maximum Value \\
\hline $\begin{array}{c}\text { Time Data from the } \\
\text { Current Situation Simu- } \\
\text { lation Model }\end{array}$ & $\mathbf{7 . 0 9 8 0}$ & $\mathbf{6 . 1 6 6 7}$ & $\mathbf{8 . 0 1 6 7}$ \\
\hline $\begin{array}{c}\text { Time Data from the Fu- } \\
\text { ture Situation Simula- } \\
\text { tion Model }\end{array}$ & $\mathbf{3 . 5 5 6 8}$ & $\mathbf{3 . 1 5 0 0}$ & $\mathbf{4 . 3 3 3 3}$ \\
\hline Difference & $\mathbf{3 . 5 4 1 2}$ & $\mathbf{3 . 0 1 6 7}$ & $\mathbf{3 , 6 8 3 4}$ \\
\hline
\end{tabular}

With VA Time, Current Situation Simulation Model Average process time which is 7.0980 minutes is shortened to 3.5568 minutes. That is why the difference between current status and future status is 3.5412 minutes. On the other hand, Current Situation Simulation Model Minimum process time which is 6.1667 minutes is shortened to $3.1500 \mathrm{mi}-$ nutes. That is why the difference between current status and future status is 3.0167 minutes. For the last value, Current Situation Simulation Model Maximum process time which is 8.0167 minutes is shortened to 4.3333 minutes. That is why the difference between current status and future status is 3.6834 minutes.

\section{CONCLUSIONS}

The purpose of this work is to improve process in a manufacturing enterprise. In this context, an enterprise operating in the manufacturing sector was dealt with and the flow of one of the products produced by this enterprise was examined and the problems in the production of the said enterprise were determined and they were tried to be eliminated.

The current situation is compared with the future situation and the performance evaluation of the company has been done. According to this study, the results and evaluations are as follows;

- A future situation model for eliminating the problems encountered in the current situation is proposed. At this stage, the simulation model of the current situation was developed. Once this model has been verified and tested for validity, the proposed future situation simulation model has been developed.

- $\quad$ Future situation simulation model and the sources which are not used effectively in the installation section are evaluated at the determined bottleneck points. In addition, two personnel were given to the assembly section which was seen as the bottleneck point and the human resource was reinforced. The product collection and control operations there were made faster.

- At the same time, it has been suggested that the processed products section on the ground floor is removed and moved to an upper floor. Mounting and paint sections on the third floor was moved to the ground floor to the vacated place. Thus, the work flow problems and loss times between the sections were eliminated.

- When the current situation is compared with the future situation, it is determined that there are 2956 differences between the current situation simulation model and the final product number of the future simulation model and it corresponds to 246 units as the average of the month. Based on these findings, it is seen that there is a $67 \%$ increase in the number of the final case simulation model in the final case compared to the current situation simulation model data.

The application of this study has been carried out with a focus on one of the products (models) produced by the pump manufacturer. Therefore, it is possible to realize the implementation of the applications in the different sectors that are concerned with the process improvement as well as the contribution of the results obtained from the study to the sector.

It is believed that study for the future studies would be contributed to the sector and the companies manufacturing pump in terms of total cost reduction, improving quality, increasing competitiveness, customer satisfaction, annual production capacity, number of final products, reduction of scrap rate and efficiency improvement works.

\section{Acknowledgment}

This study was conducted by Lecturer Mehmet Akif KARTAL under the supervision of Assistant Professor AHMET TALAT İNAN, was completed in Marmara University, Institute of Science and Technology, Department of Mechanical Engineering Department and it is derived from the master thesis titled of "Evaluation of Performance by Operating Process Improvement Modeling On a Company with Pump Manufacturing". 


\section{REFERENCES}

[1] Monks, J., G. (1996) “İşlemler Yönetimi” S. Üreten (2. Bas. Çev.), İstanbul, Nobel Yayıncılık.

[2] Bozkurt, R. (2003) "Süreç İyileştirme" 3. Basım, Ankara, MPM.

[3] Takcı, E.: 'Bir İmalat İşletmesinde Simülasyon Yardımıyla Süreç İyileştirme Uygulaması Kayseri Gürkar Tekstil Örneği’, Yüksek Lisans Tezi, Nevşehir Hacı Bektaş Veli Üniversitesi Sosyal Bilimler Enstitüsü, Nevşehir, Türkiye, (2013).

[4] Yurdakul, M.; Eşkin, S.; İç, Yusuf T.İ.:'Bir İmalat Sisteminin Yerleşim Düzeninin İyileştirilmesi', Gazi Üniversitesi Mühendislik Fakültesi, Başkent Üniversitesi Mühendislik Fakültesi, Ankara, Türkiye, (2009).

[5] Özateş, M.; Şahin, M.; Şenol, S.; Terzi, F.; Yörükoğlu, S.; Köksal, G.; Serin, Y.:'Düşük Hacimli Üretim İçin Kalite Kontrol Sistemi Tasarımı', Orta Doğu Teknik Üniversitesi Mühendislik Fakültesi, Ankara, Türkiye, (2012).

[6] Yurdakul, M.; Türkbaş, S.; Altınova, S.:'Bir İmalat Tesisinde Toplam Verimli Bakım (TVB) Uygulaması', Gazi Üniversitesi Mühendislik-Mimarlık Fakültesi, Ankara, Mercedes-Benz Türk A.Ş. Aksaray Fabrikası, Aksaray, (2008).

[7] Oran, A.:'Talaşı İmalat Optimizasyonunda Metodik Yaklaşım ve Sektörel Bir Altı Sigma Proje Uygulaması', BOSCH San. ve Tic. A.Ş. Teknik Fonksiyonlar 1 Departmanı, Bursa, Türkiye, (2012).

[8] Şahin, Ş.; Öztürk, F.:'İmalat Süreçlerindeki Problemlere Optimum Çözüm Arama ve Bir Uygulama', Uludağ Üniversitesi Mühendislik-Mimarlık Fakültesi, Bursa, (2009).

[9] Görener, A.:'Toplam Verimli Bakım ve Ekipman Etkinliği: Bir İmalat İşletmesinde Uygulama', Electronic Journal of Vocational Colleges, İstanbul, (2012).

[10] Kathiriya ${ }_{1}$, J. J.; Amareliya, V.D.; Kapadiya ${ }_{3}$, S. H.:'Production Process Analysis On Manufacturing of Hydraulic Gear Pump', 'Department of Mechanical, Shantilal Shah Engineering College, Bhavnagar, Gujarat, INDIA 2 Department of Mechanical, Mahatma Gandhi Institute of Technical Education and Research Centre, Navsari, Gujarat, INDIA ${ }_{3}$ Department of Mechanical, Mahatma Gandhi Institute of Technical Education and Research Centre, Navsari, Gujarat, INDIA, (2014).

[11] Kaljahi, B. Z.:'Reverse Engineering of Pump Impeller Utilizing Rapid Prototyping Technology', Eastern Mediterranean University the Institute of Graduate Studies and Research, Gazimağusa, North Cyprus, (2015).

[12] Tamlander, J.:'Defining a Manufacturing Planning and Control Model for a Lean Manufacturing Company', Bachelor's Thesis, JAMK University of Applied Sciences, Technology Degree Programme in Logistics Engineering, Jyväskylä, Finland, (2016).

[13] Chan, K., K. ve Spedding T., A. (2003). An Integrated Multidimensional Process Improvement Methodology for
Manufacturing Systems. Computers \& Industrial Engineering, 44(4): 673-693.

[14] Schiefer, G. (2002). Environmental Control for Process Improvement and Process Efficiency in Supply Chain Management - the Case of the Meat Chain. International Journal of Production Economics, 78(2): 197-206.

[15] Freire, J. ve Alarcon, L. (2002). Achieving Lean Design Process: Improvement Methodology. Journal of Construction Engineering and Management, 128(3): 248-256.

[16] Rohleder, T., R. ve Silver, E., A. (1997). A Tutorial on Business Process Improvement. Journal of Operations Management, 15(2): 139-154.

[17] Özveri, O. ve Kayışkan, D. (2016). Bir Gıda İşletmesinde Süreç Yönetimi ve Süreç İyileştirme Uygulaması, s. 12-25.

[18] Er, Ö. (2016). Process Improvement and an Industrial Example Over Company BSH, Bahçeşehir University, Master Thesis, İstanbul.

[19] Karaman U. (2017). Bir Finans Şirketinde Kurumsal Süreç İyileştirme ve Uygulaması, Maltepe Üniversitesi, Yüksek Lisans Tezi, İstanbul.

[20] Etleç, B. (2017). Yalın Üretim Tekniklerine Bağlı Süreç İyileştirmelerinin Bir Kozmetik Firmasında Uygulanması, Arel Üniversitesi, Sosyal Bilimler Üniversitesi, Yüksek Lisans Tezi, İstanbul.

[21] Berber, G. (2017). Bir Gıda İşletmesinde Süreç İyileştirme Uygulaması: Dondurma Fabrikası Örneği, İnönü Üniversitesi, Sosyal Bilimler Enstitüsü, Yüksek Lisans Tezi, Malatya.

[22] Sönmez, Y. (2017). Otomotiv Sektörü Süreç İyileştirmede Jishuken Uygulamaları, Sakarya Üniversitesi, Fen Bilimleri Enstitüsü, Yüksek lisans Tezi, Sakarya.

[23] Şenol, G. K. (2017). Pompa Sistemlerinde Enerji Tasarrufu ve Demir Çelik Sektöründe Örnek Bir Uygulama, İskenderun Teknik Üniversitesi, Mühendislik ve Fen Bilimleri Enstitüsü, Yüksek Lisans Tezi, Hatay.

[24] Alpaslan, İ. (2018). Otomotiv Yetkili Servisinde Müşteri Memnuniyeti Odaklı Süreç İyileştirme Çalışması: Bir Uygulama Örneği, İstanbul Medeniyet Üniversitesi / Sosyal Bilimler Enstitüsü, Yüksek Lisans Tezi, İstanbul.

[25] Sarıslan, H. (1986) "Sira Bekleme Sistemlerinde Simülasyon Tekniği” 1. Basım, Ankara, Ankara Üniversitesi Siyasal Bilgiler Fakültesi Yayınları.

[26] Prasad M. M., Aravindh A., Baskar R. and Kannan S. D.:'Implementation of Lean Manufacturing in Centrifugal Pump Assembly', Sri Krishna College of Engineering \& Technology, Kuniamuthur, Coimbatore-641008, Tamilnadu, India, (2017) 134-140. http://www.ijirset.com/upload/2017/ tapsa/17_mech_017.PDF.

[27] Aravinth K. A., Dr. Rajenthirakumar D.:'Lean Implementation through Enhancing Productivity in a Pump Industry', Department of Mechanical Engineering, United Institute of Technology, Coimbatore, TN India, (2016) 430-433. http:// ijer.in/publication/v5/097.pdf. 
[28] Kumar D.K.R., Shivashankar G.S. and Rajeshwar S. K.:'Application of Value Stream Mapping in Pump Assembly Process: A Case Study', Industrial Engineering \& Management, Barcelona, Spain (2015) 1-11. DOI: 10.4172/21690316.100.0162.

[29] Parthiban M., Perumalsamy M. and Aravinddinesh G.:'Manufacturing Lead Time Reduction in Monoblock (SWJ) Pump Industry', International Research Journal of Engineering and
Technology (IRJET), Tamilnadu, India, (2017) 1801-1807. https://www.irjet.net/archives/V4/i12/IRJET-V4I12331.pdf

[30] Prabhu C. and Aravindha B. S.:'Product and Process Improvement Using Simulation Based Value Stream Mapping: An Case Study', International Journal of Innovative Research in Science, Engineering and Technology, Tamilnadu, India, (2014) 1186-1190. http://www.rroij.com/open-access/product-and-process-improvement-usingsimulation-based-value-stream-mapping-ancase-study.pdf. 